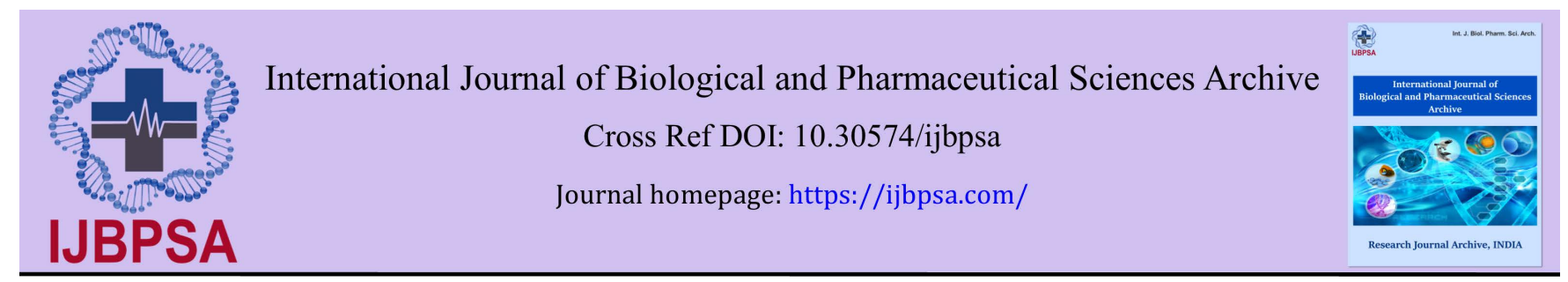

(REVIEW ARTICLE)

\title{
Medicinal plants with anticonvulsant activities with emphasis on their mechanisms of action
}

\author{
Ali Esmail Al-Snafi * \\ Department of Pharmacology, College of Medicine, University of Thi-Qar, Nasiriyah, Iraq. \\ International Journal of Biological and Pharmaceutical Sciences Archive, 2021, 01(02), 177-189 \\ Publication history: Received on 22 April 2021; revised on 25 May 2021; accepted on 28 May 2021
}

Article DOI: https://doi.org/10.30574/ijbpsa.2021.1.2.0045

\begin{abstract}
A large percent of the patients were controlled by the available antiepileptic drugs. The limited efficacy of antiepileptic drugs is still a matter of concern, $>30 \%$ of patients showed refractory epilepsy and $30-40 \%$ suffered from antiepileptic side effects. Many kinds of medicinal plants possessed antiepileptic activity, and many researchers have focused on the efficacy of their crude extracts. This review discussed the medicinal plants with antiepileptic effect focusing on active ingredients and their mode of action.
\end{abstract}

Keywords: Medicinal plants; Epilepsy; Convulsions; Antiepileptic; Anticonvulsant

\section{Introduction}

50 million people all over the world complain from epilepsy. A large percent of the patients were controlled by the available antiepileptic drugs. The limited efficacy of antiepileptic drugs is still a matter of concern, $>30 \%$ of patients showed refractory epilepsy and 30-40\% suffered from antiepileptic side effects [1-2]. Previous researches showed that many medicinal plants can possess antiepileptic effects [3-4]. They exerted antiepileptic activity by many modes of action, included modulation of neurotransmitter receptor systems, potentiating of the activity of GABA, interacting at benzodiazepine sites with a benzodiazepine agonist-type activity, blocking NMDA receptors, blocking sodium channels, and decreasing $\mathrm{Ca}^{2+}$ influx into the cell [5-10]. The current review will highlight the medicinal plants with antiepileptic effect to encourage the isolation of active principles and to perform clinical trial to investigate the clinical effects of these anticonvulsant medicinal plants.

\section{Plants with anticonvulsant effect}

\subsection{Bacopa monniera}

Crude plant extract of Bacopa monnieri or bacosides have also shown anticonvulsive action. It possessed neuroprotective effects in glutamate-mediated excitotoxicity during seizures and cognitive damage occurring in association with pilocarpine-induced epilepsy. The ethanolic extract of Bacopa monniera was tested for anticonvulsant activity using different convulsive models (pentylenetetrazol, maximal electroshock and strychnine-induced convulsion in rats, as well as hypoxic stress-induced convulsions in mice and lithium-pilocarpine-induced status epilepticus). The ethanolic extract of Bacopa monniera was administered as 50 and $55 \mathrm{mg} / \mathrm{kg}$ orally for rats and mice, respectively, 2 and 4 hours before the respective convulsive stimuli. The ethanolic extract of leaves produced significant anticonvulsant activity for all the different models studied with a mechanism of action similar to that of benzodiazepines (GABA agonist) [11-12].

\footnotetext{
* Corresponding author: Ali Esmail Al-Snafi

Department of Pharmacology, College of Medicine, University of Thi-Qar,Nasiriyah, Iraq.

Copyright (C) 2021 Author(s) retain the copyright of this article. This article is published under the terms of the Creative Commons Attribution Liscense 4.0.
} 


\subsection{Benincasa hispida}

The anticonvulsant properties of alcoholic extract of Benincasa hispidawas studied on Maximal Electro Shock Test (MEST), pentylenetetrazole and strychnine-induced seizures model in mice. The alcoholic extract of Benincasa hispida protected animals against maximal electroshock-induced convulsion and reduced the mean recovery time from convulsion. It also showed anticonvulsant activity against pentylenetetrazole-induced convulsion and protected mice against strychnine-induced convulsions [13-14].

\subsection{Brassica nigra}

The antiepileptic activity of methanolic extract of Brassica nigraseeds was investigated on maximal electroshock induced seizures (MES), Pentylenetetrazole (PTZ), Picrotoxin (PIC) and biccuculine induced seizures in mice. It was found that the extract (200 and $400 \mathrm{mg} / \mathrm{kg}$, orally), significantly prolonged the onset of tonic seizures and reduced the duration of incidence of seizures in PTZ, PIC and biccuculine induced seizure models, while in MES model, the extract showed significant effect in abolishing tonic hind limb extensions by inhibiting voltage dependant $\mathrm{Na}^{+}$channels or by blocking glutaminergic excitation mediated by the N-methyl- D-aspartate (NMDA) receptor [15].

The anti-epileptic effect of the methanolic extract of Brassica nigraseeds (75, 150 and $300 \mathrm{mg} / \mathrm{Kg}$; intra-peritoneal [ip]) was evaluated in pentylentetrazole (PTZ) - induced kindling in mice. The methanolic extract of Brassica nigra seed reduced the intensity and duration of seizure. In addition, the Brassica nigra extract increased the SOD and NO levels and decreased the MDA level in the brain tissues [16-17].

\subsection{Bryophyllum calycinum}

The $\mathrm{CH}_{2} \mathrm{Cl}_{2} / \mathrm{CH}_{3} \mathrm{OH}$ extract reduced seizures induced by pentylenetetrazol, strychnine sulphate and thiosemicarbazide and increases in the latency period of seizures and reduced the duration of seizures induced by the three convulsive agents [18-20].

\subsection{Caesalpinia crista}

The anticonvulsive effect of seed extract of Caesalpinia cristawas investigated by pentylenetetrazole, maximal electro shock strychnine- and picrotoxin-induced convulsions models. Diazepam was used as a standard reference for all models except maximal electro shock model, wherein phenytoin was used as standard reference. Seed kernels of Caesalpinia crista were powdered and subjected to successive extraction with petroleum ether, ethanol, methanol and water. All the extracts were administered as suspension in $2 \%$ gum acacia inall the experiments. In pentylenetetrazole maximal electro shock, strychnine- and picrotoxin-induced convulsion models, the medium and high doses (600 and $800 \mathrm{mg} / \mathrm{kg}$ ) of the extract showed significant anticonvulsant activity [21-22].

\subsection{Calotropis procera}

The anticonvulsant activity of different root extracts of Calotropis procera was studied in rats using seizures induced by maximal electroshock seizures (MES), pentylenetetrazol (PTZ), lithium-pilocarpine and electrical kindling seizures. In the MES test, the chloroform extract of Calotropis procera roots showed the most significant $(\mathrm{P}<0.01)$ anticonvulsant effect, it decreased the duration of hind limb extension (extensor phase), clonus and also the duration of the stupor phase compared with the controls. In the PTZ test, the chloroform extract exhibited a highly significant $(\mathrm{P}<0.001)$ effect, and the aqueous extract had a significant $(\mathrm{P}<0.01)$ effect compared with the controls by delaying the onset of convulsions. The extracts also inhibited convulsions induced by lithium-pilocarpine and electrical kindling [23-24].

\subsection{Carthamus tinctorius}

Subcutaneous administration of $1-10 \mathrm{~g} / \mathrm{kg}$ of an aqueous or $50 \%$ methanol extract of the flowers had central nervous system depressant effects and relaxed skeletal muscles in mice. Subcutaneous administration of $10 \mathrm{~g} / \mathrm{kg}$ of a $50 \%$ methanol extract of the flowers inhibited pentylenetetrazole-induced convulsions in mice [25-26].

\subsection{Cicer arietinum}

Different doses of dichloromethane extract of Cicer arietinum were administered to the mice, the pentylenetetrazole induced clonic seizure (occurrence and latency) was recorded $30 \mathrm{~min}$ thereafter. The extract protected mice against clonic seizures induced by pentylenetetrazole, dose-dependently $\left(\mathrm{ED}_{50}=3 \mathrm{~g} / \mathrm{kg}\right)$ with no toxic and lethal effects [27-29]. 


\subsection{Citrus limon}

The central nervous system (CNS) depressant and anticonvulsant activities of Citrus limon essential oil (EO) were investigated in animal models. The EO $(50,100$ and $150 \mathrm{mg} / \mathrm{kg})$ administered by oral route in mice caused a significant decrease in the motor activity of animals when compared with the control group, up to thirty days after the administration and the dose of $150 \mathrm{mg} / \mathrm{kg}$ significantly reduced the remaining time of the animals on the Rota-rod apparatus. Additionally, C. limon essential oil was also capable to promote an increase of latency for development of convulsions induced by pentylenetetrazole. The administration of flumazenil, (10 mg/kg, ip), GABA A-benzodiazepine (GABA-BZD) receptor antagonist, antagonized the effect of $C$. limon essential oil at higher dose. C. limon essential oil was also capable to promote an increase of latency for development of convulsions induced by picrotoxinat higher dose. In the same way, the anticonvulsant effect of the EO was affected by pretreatment with flumazenil, a selective antagonist of benzodiazepine site of GABAA receptor [30-31].

\subsection{Clitoria ternatea}

The spectrum of activity of the methanolic extract of Clitoria ternatea (CT) on the CNS was determined. The CT was studied for its effect on cognitive behavior, anxiety, depression, stress and convulsions induced by pentylenetetrazol (PTZ) and maximum electroshock (MES). To explain these effects, the effect of CT was also studied on behavior mediated by dopamine (DA), noradrenaline, serotonin and acetylcholine. The extract decreased time required to occupy the central platform (transfer latency, TL) in the Elevated Plus Maze (EPM) and increased discrimination index in the object recognition test, indicating nootropic activity. The extract was more active in the object recognition test than in the EPM. The extract increased occupancy in the open arm of EPM by $160 \%$ and in the lit box of the light/dark exploration test by $157 \%$, indicating its anxiolytic activity. It decreased the duration of immobility in tail suspension test (suggesting its antidepressant activity), reduced stress-induced ulcers and reduced the convulsing action of PTZ and MES. The extract exhibited tendency to reduce the intensity of behavior mediated via serotonin and acetylcholine. The effect on DA- and noradrenaline-mediated behavior was not significant. Accordingly, the extract possessed nootropic, anxiolytic, antidepressant, anticonvulsant and antistress activity [32-34].

\subsection{Coriandrum sativum}

The effects of hydroalcoholic extract of aerial parts of the plants $(100,500$ and $1000 \mathrm{mg} / \mathrm{kg})$ on brain tissues oxidative damages following seizures induced by pentylenetetrazole (PTZ) was investigated in rats. The extract significantly increased the MCS (latencies to the first minimal clonic seizures) and GTCS (latencies to the first generalized tonic-clonic seizures $)(\mathrm{P}<0.01, \mathrm{P}<0.001)$ following $\mathrm{PTZ}$-induced seizures. The malondialdehyde $(\mathrm{MDA})$ levels in both cortical and hippocampal tissues of PTZ group were significantly higher than those of the control animals $(\mathrm{P}<0.001)$. Pretreatment with the extract prevented elevation of the MDA levels $(\mathrm{P}<0.010-\mathrm{P}<0.001)$. Following PTZ administration, a significant reduction in total thiol groups was observed in both cortical and hippocampal tissues $(\mathrm{P}<0.050)$. Pre-treatment with the $500 \mathrm{mg} / \mathrm{kg}$ of the extract caused a significant decreased in total thiol concentration in the cortical tissues $(\mathrm{P}<0.010)$. Accordingly, the hydroalcoholic extract of the aerial parts of Coriandrum sativum possessed significant antioxidant and anticonvulsant activities [35].

Intraperitoneal injection of decoction and maceration extracts increased the latency of the convulsions induced by PTZ in albino mice, but failed to produce complete protection against mortality. The anticonvulsant activities of high dose extracts were similar to that of phenobarbital at a dose of $20 \mathrm{mg} / \mathrm{kg}$ in the PTZ test. In the maximal electroshock seizures, the aqueous extracts of seeds (at a dose of $0.5 \mathrm{~g} / \mathrm{kg}$ ) and the ethanolic extract (at doses of $3.5 \mathrm{and} 5 \mathrm{~g} / \mathrm{kg}$ ) decreased the duration of tonic seizures by $22.30 \%, 30.43 \%$ and $36.96 \%$, respectively [36].

\subsection{Crocus sativus}

The anticonvulsant activities of Crocus sativus stigma constituents, safranal and crocin, were studied using pentylenetetrazole (PTZ)-induced convulsions in mice. Safranal $(0.15$ and $0.35 \mathrm{mg} / \mathrm{kg}$ body weight, ip) reduced the seizure duration, delayed the onset of tonic convulsions, and protected mice from death. Crocin $(22 \mathrm{mg} / \mathrm{kg}$, ip) did not show anticonvulsant activity [37].

Safranal is an effective anticonvulsant, it was an agonist at GABAA receptors, and the nose to brain delivery via nanoparticle formulation improved its brain delivery [38-39].

\subsection{Cuminum cyminum}

The effect of the fruit essential oil of Cuminum cyminum on the epileptiform activity induced by pentylenetetrazol (PTZ) was evaluated using intracellular technique. The results demonstrated that extracellular application of the essential oil 
of Cuminum cyminum (1\% and 3\%) dramatically decreased the frequency of spontaneous activity induced by PTZ in a time and concentration dependent manner. In addition it showed protection against pentylenetetrazol-induced epileptic activity by increasing the duration, decreasing the amplitude of after hyperpolarization potential (AHP) following the action potential, the peak of action potential, and inhibition of the firing rate [40-41].

\subsection{Cuscuta planiflora}

The anticonvulsant effect of $80 \%$ methanol extract of the plants was investigated in pentylentetrazole induced seizure in mice. Different doses of extracts delayed the onset of seizure $(\mathrm{p}<0.01)$, but the duration of seizure did not change significantly. Pretreatment of animals with different doses of extracts decreased the mortality rate significantly $(\mathrm{p}<0.01)$, the percent of seizure protection was also greater than control group significantly $(\mathrm{p}<0.05)$. The most effective dose was $50 \mathrm{mg} / \mathrm{kg}$ [42-43].

\subsection{Cynodon dactylon}

The ethanol extract of aerial parts of Cynodon dactylon showed marked protection against convulsions induced by chemo convulsive agents in mice. The catecholamines contains were significantly increased in the brains of extract treated mice. The amount of GABA, which was most likely to be involved in seizure activity, was increased significantly in mice brain after six week treatment. Results revealed that the extract showed a significant anticonvulsive property by altering the level of catecholamine and brain amino acids in mice [44-45].

The ethanol extract of aerial parts of Cynodon dactylon inhibited the onset and the incidence of convulsion in a dose dependent manner against pentylenetetrazole-induced convulsion [46].

Anticonvulsant activity of ethanolic extract of Cynodon dactylon was studied against maximal electroshock and Pentylenetetrazol (PTZ) induced convulsions in mice. The extract (200, 400, $600 \mathrm{mg} / \mathrm{kg}$ ) suppressed hind limb tonic extensions induced by MES and also exhibited protective effect in PTZ-induced seizures [47-48].

\subsection{Cyperus rotuntdus}

The anticonvulsant activity of Cyperus rotundus essential oils was evaluated using MES produced convulsion in rats. The essential oil ofCyperusrotundus $500 \mathrm{mg} / \mathrm{kg}$, significantly decreased the duration $(\mathrm{p}<0.01)$, of clonus $(12.00 \pm 0.7303 \mathrm{~s})$ and stupor (74.20 $\pm 0.6325 \mathrm{~s}$ ) phase of MES induced convulsion as compared to control [49].

The anticonvulsant effect of Cyperus rotundus extract was also experimentally examined in mice. Mice received Cyperus rotundus rhizome extract at three doses $(100,200$ and $400 \mathrm{mg} / \mathrm{kg}$; ip). All groups except for control group, were kindled by 11 injections of PTZ (35 mg/kg; ip) with an interval of $48 \mathrm{~h}$. In the 12 th injection, all groups except for control group, were tested for PTZ challenge dose (75 mg/kg). The exhibited phases of seizure (0-6) were observed and noted for 30 min after PTZ injection. All brains of mice were removed and then malondialdehyde (MDA), superoxide dismutase (SOD) and Nitric Oxide (NO) levels of brain tissues were determined. Data analysis showed that the hydroalcoholic extract of Cyperus rotundus reduced intensity and duration of seizure and increased the level of SOD and NO and decrease MDA level in mice brain [50].

The anticonvulsant effect of Cyperus rotundus roots and rhizomes was studied in seizures induced by pentylenetetrazol (PTZ) and picrotoxin (PTX) in mice. Pretreatment with hydroalcoholic extract of Cyperus rotundus roots and rhizomes $(50-200 \mathrm{mg} / \mathrm{kg})$ induced a dose-dependent decrease in the incidence of both clonic and generalized tonic-clonic seizures ( $\mathrm{p} \leq 0.05)$ following PTZ and PTX administration. Co-administration of a sub-effective dose of CR (50 mg/kg, po) with a sub-protective dose of diazepam $(0.5 \mathrm{mg} / \mathrm{kg}$, ip) increased the latency to seizure. The combination significantly enhanced percent protection against PTZ and PTX induced convulsions. The authors suggested that the anticonvulsant effect of Cyperus rotundu sroots and rhizomes against PTZ and PTX induced convulsions may be mediated, at least partly, through GABA A-benzodiazepine receptor complex [51].

Pretreatment with the ethanol extract of Cyperus rotundus caused significant protection against strychnine and leptazolinduced convulsions [52-53].

\subsection{Equisetum arvense}

In studying of sedative and anticonvulsant effects of Equisetum arvense, hydroalcoholic extract of Equisetum arvense (200 and $400 \mathrm{mg} / \mathrm{kg}$ ) showed significant activity on the open-field, enhanced the number of falls in the rota-rod reducing the time of permanence in the bar and increased the sleeping time (46\% and $74 \%$ respectively) in the barbiturate-induced sleeping time. In the pentylenetetrazole-seizure, it increased the first convulsion latency, 
diminished the severity of convulsions, reduced the percentage of animals which developed convulsion (50\% and $25 \%$ respectively) and protected animals from death. However, in the elevated plus maze, the doses 50,100 and $150 \mathrm{mg} / \mathrm{kg}$ did not affect the evaluated parameters [54-55].

\subsection{Eschscholzia californica}

The sedative effects of alkaloids detected in E. californica were attributed to chloride-current modulation, which were widely expressed in the brain mainly at the inhibitory interneurons. Electrophysiological studies on a recombinant $\alpha 1$ $\beta 2 \gamma 2$ GABAA receptor showed no effect of N-methyl laurotetanine at concentrations lower than $30 \mu \mathrm{M}$. However, $(S)$ reticuline behaved as positive allosteric modulator at the $\alpha 3, \alpha 5$, and $\alpha 6$ isoforms of GABAA receptors. The depressant properties of aerial parts of E. californica were assigned to chloride-current modulation by $(S)$-reticuline at the $\alpha \beta 2 \gamma 2$ and $\alpha 5 \beta 2 \gamma 2$ GABAA receptors [56].

Protopine, cryptopine and allocryptopine were demonstrated to enhance 3H-gamma-aminobutyric acid (3H-GABA) binding to rat brain synaptic membrane receptors. This effect might be indicate a benzodiazepine-like activity of these alkaloids [57-58].

\subsection{Gossypium species}

The antiepileptic activity of aqueous extract of Gossypium herbaceum (AEGH) at 10, 30, and $100 \mathrm{mg} / \mathrm{Kg}$, po was evaluated by the convulsions induced in mice by maximum electroshock (MES), pentylenetetrazole (PTZ) and isoniazid (INH). In MES method, aqueous extract of Gossypium herbaceum inhibited convulsions significantly potent than Diazepam. In PTZ method, aqueous extract of Gossypium herbaceum inhibited convulsions potent than phenobarbitone sodium. In INH method, aqueous extract of Gossypium herbaceum delayed the onset of convulsions with a potency less than Diazepam [59-60].

\subsection{Hibiscus rosa-sinensis}

The ethanolic extracts of flowers of Hibiscus rosasinesis exhibited anticonvulsant activity. The bioassay guided fractionation indicated that the anticonvulsant activity lies in the acetone soluble part of ethanolic extract of $H$. rosasinesis flowers. The fraction protected animals from maximum electro shock, electrical kindling and pentylenetetrazole-induced convulsions in mice and inhibited convulsions induced by lithium-pilocarpine and electrical kindling. It antagonised the behavioral effects of $\mathrm{D}$-amphetamine and potentiated the pentobarbitone-induced sleep. It raised brain contents of gamma-aminobutyric acid (GABA) and serotonin [61-62].

\subsection{Hyoscyamus niger}

The anticonvulsant effects of alcoholic extract of Hyoscyamus niger seed in doses of 50, 100 and $200 \mathrm{mg} / \mathrm{kg}$ ip, was evaluated in seizure induced by Pentylenetetrazole. The results showed that administration of Hyoscyamus niger seed extract possessed inhibitory effect on the steps, progression and duration of seizure, especially in the last steps of convulsion. However, therapy with henbane seed extract resulted in an efficient anticonvulsive effect from the 8th injection reaching the highest level of efficiency at the 12th $(p<0.001)[63]$.

The effects of methanolic extract of Hyoscyamus niger on seizures induced by picrotoxin was studied in mice. Groups of mice were pretreated with methanolic extract of the plant $(12.5,25,50,100,200,300,400 \mathrm{mg} / \mathrm{kg}$, ip), 20 minutes prior to the picrotoxin $(12 \mathrm{mg} / \mathrm{kg}$, ip)-induced seizures. The latency of seizure (sec), duration of seizure (sec) and mortality rate were determined in test and control groups. The results showed that latency of seizure was increased in groups pretreated with $100,200,300$ and $400 \mathrm{mg} / \mathrm{kg}$ of extract, furthermore, methanolic extract also $(200-400 \mathrm{mg} / \mathrm{kg})$ significantly $(\mathrm{P}<0.01)$ delayed the death time in mice as compared to control [64-65].

\subsection{Juglans regia}

The potential anticonvulsant effect of Walnut Kernel Extract (WKE) was evaluated in pentylenetetrazole (PTZ; 2 $\mathrm{mg} / \mathrm{ml} / \mathrm{min}$ ) induced seizures in rats.WKE administration significantly increased the PTZ dose needed to induce the first myoclonic jerk $(13.09 \pm 1.29$ vs. $49.71 \pm 12.03 \mathrm{mg} / \mathrm{kg} ; \mathrm{p}<0.001)$, decreased the severity of seizure grades and reduced the mortality rate to $0 \%$. Flumazenil (FMZ; $5 \mathrm{mg} / \mathrm{kg}$ ip), did not significantly reduce the anticonvulsant effect of WKE. The combination of diazepam (DPZ; $0.5 \mathrm{mg} / \mathrm{kg}$ ip) and WKE showed a synergic anticonvulsant effect, whereas ethosuximide (ESM) had no significant influence ( $p>0.05$ ) on the WKE effects. It seemed that the anticonvulsant effect attributed to signaling pathways other than benzodiazepine mediated $\gamma$-aminobutyric acid receptors [66-67]. 


\subsection{Juniperus oxycedrus}

Pretreatment with methanol and dicliloromethanol extracts $(200 \mathrm{mg} / \mathrm{kg})$ did not modify the duration of convulsions induced by electrical stimulation in mice [68-69].

\subsection{Lagerstroemia speciosa}

The anticonvulsant activity of bark extracts of Lagerstroemia speciosa was studied in isoniazid and pilocarpine induced convulsions models. By both models, $400 \mathrm{mg} / \mathrm{kg}$ of extract showed significant anticonvulsant activity by delaying the onset of convulsions [70].

In phenobarbitone- induced sleeping time test, Lagerstroemia speciosa flower extract delayed the onset of sleep (30.22 $\mathrm{min}$ and $38.61 \mathrm{~min}$ at 200 and $400 \mathrm{mg} / \mathrm{kg} \mathrm{bw}$, respectively). The extract was also found to shorten total sleeping time (99.45 $\mathrm{min}$ and $107.6 \mathrm{~min}$ at 200 and $400 \mathrm{mg} / \mathrm{kg}$ bw, respectively) [71-72].

\subsection{Lawsonia inermis}

The chloroform, ethanol and water extracts of the leaves of Lawsonia inermis $(20 \mathrm{mg} / \mathrm{kg}$, bw) were investigated for anticonvulsant activity using electroshock method in mice. Chloroform and ethanol extracts exhibited anticonvulsant activity but more significant activity was recorded for the chloroform extract [73-74].

\subsection{Leontice leontopetalum}

The alkaloid petaline chloride, obtained from extracts of Leontice leontopetalum was more potent convulsant poison than leptazol. However, it reduced the convulsant activity of leptazol and gave some protection from electrically induced seizures at lower dose. It depressed both the patellar tendon reflex and the crossed extension reflex, it also possessed muscle relaxant activity and increases the rate, force and amplitude of the beat of the isolated auricle depressed in a low calcium medium [75-76].

\subsection{Lippia nodiflora}

The antiepileptic effects of petroleum, chloroform and ethanolic extracts of aerial part of Lippia nodiflora was evaluated in experimental models of electroshock convulsions. The results showed that the ethanolic extract of Lippia nodiflora at both doses ( 250 and $500 \mathrm{mg} / \mathrm{kg}$ orally) and its chloroform extract at a higher dose of $500 \mathrm{mg} / \mathrm{kg}$ produced significant anticonvulsant effects in mice [77-78].

\subsection{Matricaria recutita}

The antiepileptic effect of hydro-methanolic percolated extract of Matricaria recutita $(100,200$, and $300 \mathrm{mg} / \mathrm{kg}) \mathrm{in}$ seizure induced by picrotoxin was studied in mice. The latency of the beginning time of seizure was increased in mice pretreated with different doses of extract. The most effective dose was $200 \mathrm{mg} / \mathrm{kg}(\mathrm{P}<0.05)$. The same dose delayed the time of death in mice $(\mathrm{P}<0.01)$. The extract showed no effect on the death rate [79].

The anticonvulsant effects of hydro-alcoholic extract of Matricaria chamomilla on PTZ-induced seizure were studied in rats. Different doses of extract delayed the initiation time of tonic-clonic seizures in comparison with control group. The delay was significant at $600 \mathrm{mg} / \mathrm{kg}(\mathrm{P}<0.05), 800$ and $1000 \mathrm{mg} / \mathrm{kg}(\mathrm{P}<0.001)$. The extract also significantly decreased the $24 \mathrm{~h}$ death at 800 and $1000 \mathrm{mg} / \mathrm{kg}(\mathrm{P}<0.01)$ and $600 \mathrm{mg} / \mathrm{kg}(\mathrm{P}<0.05)$ [80].

The protective effect of ethyl acetate fraction of Matricaria recutita $(25 \mathrm{mg} / \mathrm{kg}$, bw) against strychnine induced seizure was studied in mice in comparison with diazepam $0.5 \mathrm{mg} / \mathrm{kg}$. Both treatments were given intraperitoneally 60 minutes before the administration of strychnine. Both, ethyl acetate fraction of Matricaria recutita and standard drug showed significant increase in the onset time to seizure and the survival time with obvious decrease in the severity of the attack compared to control [81-82].

\subsection{Nerium oleander}

The central nervous activity of $50 \%$ hydroalcoholic flower extract (100 and $200 \mathrm{mg} / \mathrm{kg}$ orally) of Nerium oleander was studied in mice. The anticonvulsant activity was determined by electroshock and pentyleneterazol- induced convulsion. The extract (at $200 \mathrm{mg} / \mathrm{kg}$ ) showed $66 \%$ protection against electroshock-induced convulsions, while the lower dose $(100 \mathrm{mg} / \mathrm{kg})$ produced a significant reduction $(\mathrm{P}<0.01)$ in pentylenetetrazol-induced convulsions [83]. 
Two fractions B-1 and B-3 purified from the methanolic extract of fresh, undried and uncrushed leaves of Nerium oleander, were studied for antiepileptic effects. Fraction B-1 showed 40\% protection against picrotoxin induced convulsions, while fraction B- 3 exhibited 60\% protection against bicuculline induced convulsions [84-85].

\subsection{Nigella sativa}

The anticonvulsant effect of Nigella sativa seed extracts of different germination phases was studied in experimental animals using maximal electroshock seizure model, with the using of diazepam $(20 \mathrm{mg} / \mathrm{kg})$ as a positive control. All the extracts of Nigella sativa from different germination phases exhibited significant $(\mathrm{P}<0.001)$ reduction in various phases of epileptic seizure on comparison with the diazepam [86].

The anticonvulsant effect of thymoquinone, was investigated using pentylenetetrazole (PTZ)-and maximal electroshock (MES)-induced seizure models in mice. In PTZ-induced seizure, thymoquinone at 40 and $80 \mathrm{mg} / \mathrm{kg}$, ip, prolonged the onset of seizures and reduced the duration of myoclonic seizures. The protective effect of thymoquinone against mortality was $71.4 \%$ and $100 \%$, respectively. However, thymoquinone failed to reduce the duration of seizure, but exhibited a complete protection against mortality, in MES model [87].

Sinilarly, the effects of Nigella sativa hydroalcoholic extract on neural damage after pentylenetetrazole (PTZ) - induced repeated seizures were studied in rats. Hydroalcoholic extract treated rats showed lower seizure scores than PTZ group [88].

Nigella sativaoil was investigated for its ability to suppress the convulsive and lethal effects of pentylenetetrazole in kindled mice in comparison with valproate, and for its ability to attenuate the pentylenetetrazole -induced oxidative injury in the brain tissue. Nigella sativa oil was found to be more effective than valproate in preventing pentylenetetrazole - induced seizures, and it significantly decreased oxidative injury in the mouse brain tissue [89].

The antioxidant and antiepileptic effects of curcumin, Nigella sativa oil and valproate were studied in the pilocarpineinduced rat model of chronic epilepsy. Curcumin, Nigella sativa oil or valproate for 21 days ameliorated most of the changes induced by pilocarpine, they reversed the levels of malondialdehyde, nitric oxide and reduced glutathione and restored the activities of CAT, $\mathrm{Na}^{+}, \mathrm{K}^{+}$-ATPase, reduced acetylcholinesterase in the hippocampus, and reduced seizures [90].

The aqueous extract, fixed oil and volatile oil of Nigella sativa seed and its major active constituents (thymoquinone, $\alpha$ pinene and p-cymene) were investigated against pentylenetetrazole (PTZ) and maximal electroshock (MES)-induced convulsions. All the Nigella sativa seed constituents protected mice effectively against PTZ-induced convulsions except fixed oil. Volatile oil and its component p-cymene, effectively suppressed convulsions induced by MES. All of the Nigella sativa seed constituents induced varying degrees of minimal neurological deficit in the Chimney test the picrotoxin and bicuculline-sensitive GABA receptors, most probably GABAA receptors, mediated an increase in GABA-ergic response [91].

The anticonvulsant effect of the aqueous extract of black seed (40 mg/kg/8 h, as an adjunct therapy for four weeks) was investigated clinically, a double-blind crossover placebo controlled clinical trial was conducted in children (13 months to 13 years) with refractory epilepsy. The frequency of seizures was significantly decreased in the children receiving Nigella sativa extract compared to placebo $(\mathrm{P}<0.05)$ [92].

\subsection{Ocimum basilicum}

The anticonvulsant effects of the essential oil were investigated using pentilenetetrazole- and picrotoxin- induced convulsion in mice. Essential oil, at the doses of 200 and $400 \mathrm{mg} / \mathrm{kg}$ increased the latencies for the onset of the tonicclonic convulsions induced by pentilenetetrazole $(\mathrm{P}<0.01)$. The percentage of convulsed animals was decreased by essential oil at the doses of $200(\mathrm{P}<0.05)$ and $400 \mathrm{mg} / \mathrm{kg}(\mathrm{P}<0.01)$. Essential oil, at the doses of $200 \mathrm{and} 400 \mathrm{mg} / \mathrm{kg}$ $(\mathrm{P}<0.01)$ increased the latencies for the onset of the tonic-clonic convulsions induced by picrotoxin. The percentage of animals that convulsed was also decreased by essential oil [93-94].

\subsection{Onopordon acanthium}

The antiepileptic effect of Onopordon acanthiums econdary metabolite (onopordia) [0.1, 1 and $10 \mathrm{mg} / \mathrm{kg}$, ip, 30, 60 and $120 \mathrm{~min}$ prior to induction of epileptic seizure], was investigated in pentylenetetrazole (PTZ)-induced seizure in male mice with the investigation of possible role of nitric oxide pathway. Onopordia possessed anticonvulsant effects when administrated at dose of $10 \mathrm{mg} / \mathrm{kg}$, ip and the optimum time was $60 \mathrm{~min}$ prior to induction of seizure. Anticonvulsant 
effect of onopordia was blocked by applying a single dose of a non-selective nitric oxide synthase (NOS) inhibitor, N $\omega$ nitro-L-arginine methyl ester hydrochloride (10 mg/kg, ip), and also a single dose of a selective neuronal NOS inhibitor, 7 -nitroindazole (30 mg/kg, ip). Administration of ketamine as an N-Methyl-D-aspartic acid receptor antagonist (0.5 $\mathrm{mg} / \mathrm{kg}$; ip) with onopordia did not change the anticonvulsant effect of onopordia. The results indicated that the antiepileptic effect of onopordia was attributed to NO/nNOS pathway on PTZ-induced seizure in mice [95].

\subsection{Orchis mascula}

The antiepileptic effect of hydroalcholic extract of Orchis mascula tuber (orally 30 min before induction of seizures) was evaluated against seizures, seizure-induced oxidative stress and cognitive deficit in pentylenetetrazole and maximal electroshock-induced seizures in rats. The extract produced $33.3 \%, 50 \%$ and $66.7 \%$ protection in pentylenetetrazole model and $16.7 \%, 16.7 \%$ and $33.3 \%$ at 250, 500 and $1000 \mathrm{mg} / \mathrm{kg}$, respectively, in maximal electroshock-induced seizures. Pre-treatment with the extract significantly decreased the retention transfer latency in elevated plus maze test, and an increase in the retention latency in passive avoidance test. Oxidative stress induced by seizures was also attenuated as indicated by significant increase in GSH and decrease in MDA levels in extract treated groups. Furthermore, pentylenetetrazole and maximal electroshock-induced seizures, caused a significant decrease in AchE and BChE activities, which was prevented by the extract [96-97].

\subsection{Oxalis corniculata}

The effect of methanolic extract of Oxalis corniculataon antioxidant enzymes in rat brain after induction of seizures by maximal electroshock (MES) and pentylenetetrazole (PTZ) was studied in rats. Superoxide dismutase, glutathione peroxidase, glutathione reductase and catalase were decreased in rat brain due to seizure and were restored significantly by administration of ethanol extract of Oxalis corniculata treated rats. Methanolic extract also significantly decreased lipid peroxidation in both models. The anticonvulsant activity of methanolic extract could be attributed to antioxidant properties which delayed the generation of free radical in MES and PTZ induced epilepsy [98].

The antiepileptic activity of methanol extract of leaves (200 and 400mg/kg bw) of Oxalis corniculata was screened for antiepileptic activity on maximal electroshock (MES) and pentylenetetrazole (PTZ) induced seizures models in albino Wistar rats. The extract showed significant reduction in duration of hind leg extension with $200 \mathrm{mg} / \mathrm{kg} \mathrm{dose.} \mathrm{Similar}$ dose dependent results were obtained in PTZ model, by delayed the onset of clonic convulsions. The complete protective effect against mortality was reported in both the tests [99].

The effect of methanolic (95\%) extract of Oxalis corniculata on biogenic amines concentrations in rat brain was studied to investigate the relationship between seizure activities and altered the monoamines such as noradrenaline (NA), dopamine (DA), serotonin (5-HT) and gamma amino butyric acid (GABA) in forebrain of rats in MES and PTZ seizure models. In MES model, the extract (200 and $400 \mathrm{mg} / \mathrm{kg}$ ) significantly restored the decreased levels of brain monoamines such as NA, DA, 5- HT and GABA. Similarly in PTZ model, the extract significantly increased the monoamines in forebrain of rats [100].

\section{Conclusion}

The limited efficacy of antiepileptic drugs is still a matter of concern, $>30 \%$ of patients showed refractory epilepsy and $30-40 \%$ suffered from antiepileptic side effects, which motivate researchers to develop novel approaches to treat epilepsy. Medicinal plants can possess antiepileptic activity by many modes of action, included modulation of neurotransmitter receptor systems, potentiating of the activity of GABA, interacting at benzodiazepine sites with a benzodiazepine agonist-type activity, blocking NMDA receptors, blocking sodium channels, and decreasing Ca ${ }^{2+}$ influx into the cell. The therapeutic efficacy of medicinal plants with least side effects, accelerated the research regarding natural sources of drugs. The current review highlighted the medicinal plants with antiepileptic effect to encourage the researches in this direction.

\section{Compliance with ethical standards}

\section{Acknowledgments}

We acknowledged the dean of ThiQar College of medicine for the scientific support. 


\section{References}

[1] Manchishi SM. Recent advances in antiepileptic herbal medicine. Curr Neuropharmacol 2018; 16(1): 79-83.

[2] Zhu HL, Wan JB, Wang YT, Li BC, Xiang C, He J, Li P. Medicinal compounds with antiepileptic/anticonvulsant activities. Epilepsia. 2014;55(1):3-16.

[3] Al-Snafi AE. Therapeutic properties of medicinal plants: a review of medicinal plants with central nervous effects (part 1). Int J of Pharmacology \& Toxicology 2015; 5(3): 177-192.

[4] Al-Snafi AE. Medicinal plants with central nervous effects (part 2): plant based review. IOSR Journal of Pharmacy 2016; 6(8): 52-75.

[5] Park HG, Yoon SY, Choi JY, et al. Anticonvulsant effect of wogonin isolated from Scutellaria baicalensis. Eur J Pharmacol 2007; 574: 112- 119.

[6] Ribeiro RA, Leite JR. Nantenine alkaloid presents anticonvulsant effect on two classical animal models. Phytomedicine 2003; 10: 563- 568.

[7] Charveron M, Assie MB, Stenger A, et al. Benzodiazepine agonist-type activity of raubasine, a rauwolfiaserpentina alkaloid. Eur J Pharmacol 1984; 106: 313- 317.

[8] da Silva AFS, de Andrade JP, Bevilaqua LRM, et al. Anxiolytic-, antidepressant- and anticonvulsant-like effects of the alkaloid montanine isolated from Hippeastrumvittatum. Pharmacol Biochem Behav 2006; 85: $148-154$.

[9] Lin MT, Wang JJ, Young MS. The protective effect of dl-tetrahydropalmatine against the development of amygdala kindling seizures in rats. Neurosci Lett 2002; 320: 113-116.

[10] Ameri A. Inhibition of rat hippocampal excitability by the plant alkaloid 3-acetylaconitine mediated by interaction with voltage-dependent sodium channels. Naunyn Schmiedebergs Arch Pharmacol 1997; 355: $273-28$.

[11] Kaushik D, Tripathi A, Tripathi R, Ganachari M and Khan SA. Anticonvulsant activity of Bacopa monniera in rodents. Brazilian Journal of Pharmaceutical Sciences 2009; 45: 643-649.

[12] Al-Snafi AE.The pharmacology of Bacopa monniera. A review. International Journal of Pharma Sciences and Research 2013; 4(12): 154-159.

[13] Nimbal SK, Venkatrao N, Pujar B, Shalam S, Ladde S. Evaluation of anticonvulsant activity of alcoholic extract of Benincasahispida (Thunb) Cogn. Fruit extracts. International Research Journal of Pharmacy 2011; 2(12): 166168.

[14] Al-Snafi AE. The Pharmacological Importance of Benincasa hispida. A review. Int Journal of Pharma Sciences and Research 2013; 4(12): 165-170.

[15] Uppala PK, Naga Phani K, Murali Krishna B, Swarnalatha M. Evaluation of anti-epileptic activity of methanolic extract of Brassica nigra seeds in mice. International Journal of Pharmaceutical Innovations 2013; 3(2): 73-84.

[16] Kiasalari Z, Khalili M, Roghani Mand Sadeghian A. Antiepileptic and antioxidant effect of Brassica nigra on pentylenetetrazol-induced kindling in mice. Iranian Journal of Pharmaceutical Research 2012; 11 (4): 12091217.

[17] Al-Snafi AE. The pharmacological importance of Brassica nigra and Brassica rapa grown in Iraq. J of Pharm Biology 2015; 5(4):240-253.

[18] Al-Snafi AE. The Chemical constituents and pharmacological effects of Bryophyllum calycinum- A review. Journal of Pharma Sciences and Research 2013; 4(12): 171-176.

[19] Nguelefack TB, Nana P, Atsamo AD, Dimo T, Watcho P, Dongmo AB, Tapondjou LA, Njamen D, Wansi SL and Kamanyi A. Analgesic and anticonvulsant effects of extracts from the leaves of Kalanchoecrenata (Andrews) Haworth (Crassulaceae). J Ethnopharmacol 2006; 106(1): 70-75.

[20] Hossan MS and Yemitan OK. Neuropharmacological effects of aqueous leaf extract of Bryophyllum pinnatum in mice. African Journal of Biomedical Research 2009: 101-107.

[21] Rao NV, Shalam MD, Gouda TS and Kumar SM. Anticonvulsant effect of seed extract of Caesalpinia bonducella (Roxb). Int J Pharmacy Tech 2009; 8: 51-55

[22] Al-Snafi AE. Pharmacology and medicinal properties of Caesalpinia crista - An overview. International Journal of Pharmacy 2015; 5(2): 71-83. 
[23] Al-Snafi AE. The constituents and pharmacological properties of Calotropis procera- An Overview. International Journal of Pharmacy Review \& Research 2015; 5(3): 259-275.

[24] Al-Snafi AE. The constituents and pharmacological properties of Calotropis procera- An Overview. International Journal of Pharmacy Review \& Research 2015; 5(3): 259-275.

[25] Kasahara Y, Kumaki K and Katagiri S. Pharmacological studies on flower petals of Carthamus tinctorius central actions and antiinflammation. ShoyakugakuZasshi 1989; 43: 331-338.

[26] Al-Snafi AE. The chemical constituents and pharmacological importance of Carthamus tinctorius - An overview. Journal of Pharmaceutical Biology 2015; 5(3): 143-166.

[27] Motahareh A, Mohammad S, Soroush S, Mohammad K and Narenjkar J. Evaluation of anticonvulsant activity of Cicer arietinum in mice. Iranian Conference of Physiology and Pharmacology, Physiology and Pharmacology Society, Mashhad University of Medical Sciences 2009.

[28] Al-Snafi AE. The medical Importance of Cicer arietinum - A review. IOSR Journal of Pharmacy 2016; 6(3): 29-40.

[29] Sardari S, Amiri M, Rahimi H, Kamalinejad M, Narenjkar J, Sayyah M. Anticonvulsant effect of Cicer arietinum seed in animal models of epilepsy: introduction of an active molecule with novel chemical structure. Iran Biomed J 2015;19(1):45-50.

[30] Campêlo LML, Gonçalves FCM, Feitosa CM andFreitas RM. Evaluation of central nervous system effects of Citrus limon essential oil in mice. RevistaBrasileira de Farmacognosia (Brazilian Journal of Pharmacognosy) 2011; 21(4):668-673.

[31] Al-Snafi AE. Nutritional value and pharmacological importance of citrus species grown in Iraq. IOSR Journal of Pharmacy 2016; 6(8): 76-108.

[32] Jain NN, Ohal CC, Shroff SK, Bhutada RH, Somani RS, Kasture VS and Kasture SB. Clitoria ternatea and the CNS. Pharmacology Biochemistry and Behavior 2003; 75(3): 529-536.

[33] Al-Snafi AE. Pharmacological importance of Clitoria ternatea - A review. IOSR Journal of Pharmacy 2016; 6(3): 68-83.

[34] Vyawahare NS, Nikam AP, Sharma RG, Deshpande MM, Tarnalli AD and Bodhankar SL. Effect of Clitoria ternatea extract on radial arm maze task performance and central cholinergic activity in rats. J cell tissue Res 2007; 7(1): 949-52.

[35] Karami R, Hosseini M, Mohammadpour T, Ghorbani A, Sadeghnia HR, Rakhshandeh H, Vafaee F and Esmaeilizadeh M. Effects of hydroalcoholic extract of Coriandrum sativum on oxidative damage in pentylenetetrazole-induced seizures in rats. Iran J Neurol 2015;14(2):59-66.

[36] Al-Snafi AE. A review on chemical constituents and pharmacological activities of Coriandrum sativum. IOSR Journal of Pharmacy 2016; 6(7): 17-42.

[37] Hosseinzadeh $\mathrm{H}$ and Khosravan V. Anticonvulsant effects of aqueous and ethanolic extracts of Crocus sativus $\mathrm{L}$. stigma in mice. Arch Irn Med2002; 5 (1): 44-47.

[38] Pathan SA, Alam S, Jain GK, Zaidi SM, Akhter S, Vohora D, Khar RK and Ahmad FJ. Quantitative analysis of safranal in saffron extract and nanoparticle formulation by a validated high-performance thin-layer chromatographic method. Phytochem Anal 2010; 21(3):219-223.

[39] Al-Snafi AE. The pharmacology of Crocus sativus- A review. IOSR Journal of Pharmacy 2016; 6(6): 8-38.

[40] Janahmadi M, Niazi F, Danyali S andKamalinejad M. Effects of the fruit essential oil of Cuminum cyminum Linn (Apiaceae) on pentylenetetrazol-induced epileptiform activity in F1 neurones of Helix aspersa. J Ethnopharmacol 2006; 104(1-2): 278-282.

[41] Al-Snafi AE.The pharmacological activities of Cuminum cyminum - A review. IOSR Journal of Pharmacy 2016; 6(6): 46-65.

[42] MehrabaniM ,Modirian E, Ebrahimabadi AR, Vafazadeh J, Shahnavaz S and Heidari MR. Study of the effects of hydro-methanol extracts of Lavandula vera DC. and Cuscuta epithymum Murr. on the seizure induced by pentylentetranzol in mice. Journal of Kerman University of Medical Sciences 2007; (1):44-54.

[43] Al-Snafi AE. Traditional uses, constituents and pharmacological effects of Cuscuta planiflora. The Pharmaceutical and Chemical Journal 2016; 3(4): 215-219. 
[44] Pal DK. Determination of brain biogenic amines in Cynodon dactylon L. (Pers) and Cyperus rotundus L treated mice. Int J Pharm Pharm Sci 2009; 1: 190-197.

[45] Al-Snafi AE.Chemical constituents and pharmacological effects of Cynodon dactylon- A review. IOSR Journal of Pharmacy 2016; 6(7):17-31.

[46] Pal D. Evaluation of CNS activities of aerial parts of Cynodon dactylon Pers in mice. Drug Research 2008; 65(1): 37-43.

[47] Garg VK and Paliwa SK. Anticonvulsant activity of ethanolic extract of Cynodon dactylon. Der Pharmacia Sinica 2011; 2 (2):86-90.

[48] Al-Snafi AE. Chemical constituents and pharmacological effects of Cynodon dactylon- A review. IOSR Journal of Pharmacy 2016; 6(7):17-31.

[49] Biradar S, Kangralkar VA, Mandavkar YM, Thakur M and Chougule. Anti-inflammatory, antiarthritic, analgesic and anticonvulsant activity of Cyperus essential oils. Int J Pharm PharmSci 2010; 294 (4): 112-115.

[50] Khalili M,Kiasalari Z,Roghani M andAzizi Y. Anticonvulsant and antioxidant effect of hydroalcoholic extract of Cyperus rotundus rhizome on pentylentetrazole-induced kindling model in male mice. Journal of Medicinal Plants Research 2011; 5(7):1140-1146.

[51] Mayur P, Pawan P, Ashwin S and Pravesh S. Evaluation of anticovulsant activity of roots and rhizomes of Cyperus rotundus Linn in mice. International Research Journal of Pharmacy 2011; 2 (10): 37-41.

[52] Pal D, Dutta S and Sarkar A. Evaluation of CNS activities of ethanol extract of roots and rhizomes of Cyperus rotundus in mice. Acta Pol Pharm 2009; 66(5): 535-541.

[53] Al-Snafi AE.A review on Cyperus rotundus. A potential medicinal plant. IOSR Journal of Pharmacy 2016; 6(7):3248.

[54] Dos Santos Jr JG, Blancoa MM, Do Monteb FHM, Russib M, Lanziottib VNMB, Lealc LKAM and Cunhac GM. Sedative and anticonvulsant effects of hydroalcoholic extract of Equisetum arvense. Fitoterapia 2005; 76(6): 508-513.

[55] Al-Snafi AE. The pharmacology of Equisetum arvense- A review. IOSR Journal of Pharmacy 2017;7(2):31-42.

[56] Fedurco M, Gregorová J, Šebrlová K, Kantorová J, Peš O, Baur R,Sigel E and Táborská E. Modulatory effects of Eschscholzia californica alkaloids on recombinant GABAA receptors. Hindawi Publishing Corporation Biochemistry Research International 2015,http://dx.doi.org/10.1155/2015/617620

[57] Al-Snafi AE. Eschscholzia californica: A phytochemical and pharmacological review. Indo Am J P Sci 2017; 4(02): 257-263.

[58] Rolland A, Fleurentin J, Lanhers MC, Misslin R, Mortier F. Neurophysiological effects of an extract of Eschscholzia californica Cham. (Papaveraceae). Phytother Res 2001;15(5):377-381.

[59] Sumalatha G and Sreedevi A.Evaluation of antiepileptic activity of aqueous extract of leaves of Gossypiumherbaceum in mice. Int J Pharm Bio Sci 2012; 2(4):349-353.

[60] Al-SnafiAE.Chemical constituents and pharmacological activities of Gossypium herbaceum and Gossypium hirsutum - A review. IOSR Journal ofPharmacy 2018; 8(5): 64-80.

[61] Kasture VS, Chopde CT and Deshmukh VK. Anticonvulsive activity of Albizzia lebbeck, Hibiscus rosa-sinensis and Butea monosperma in experimental animals. J Ethanopharmacol 2000; 71(1-2): 65-75.

[62] Al-Snafi AE. Chemical constituents, pharmacological effects and therapeutic importance of Hibiscus rosa-sinensisA review.IOSR Journal of Pharmacy 2018; 8 (7): 101-119.

[63] Kiasalari Z, Khalili M and Heidari H. Anti-convulsant effect of alcoholic Hyoscyamus niger L seed extract on PTZ model of kindling in male mice. Razi Journal of Medical Sciences 2011; 18(85): 27-33.

[64] Reza HM, Mohammad H, Golnaz E and Gholamreza S. Effect of methanolic extract of Hyoscymus niger L. on the seizure induced by picritoxin in mice. Pak J Pharm Sci 2009;22(3):308-312

[65] Al-Snafi AE. Therapeutic importance of Hyoscyamus species grown in Iraq (Hyoscyamus albus, Hyoscyamus niger and Hyoscyamus reticulates)- A review. IOSR Journal of Pharmacy 2018; 8(6): 18-32.

[66] Asadi-Shekaari M, Eslami A and Kalantaripour T. Potential mechanisms involved in the anticonvulsant effect of walnut extract on pentylenetetrazole-induced seizure. Med Princ Pract 2014;23:538-542. 
[67] Al-Snafi AE. Chemical constituents, nutritional, pharmacological and therapeutic importance of Juglans regia- A review. IOSR Journal of Pharmacy 2018; 8(11): 1-21.

[68] Al-Snafi AE. Pharmacological and therapeuticeffects of Juniperus oxycedrus- A review. 2018; 5 (4): 2198-2205.

[69] Tavares WR, Seca AML. The Current status of the pharmaceutical potential of Juniperus L. metabolites. Medicines (Basel) 2018;5(3):81.

[70] Bhowmik NR, MoghaMR,Barua S et al. Characterization of phyto-constituents and evaluation of gastrointestinal motility \& anticonvulsant activities of Lagerstroemia speciosalinn (bark). World Journal of Pharmaceutical Sciences 2016; 4(3):309-313.

[71] Sharmin T, Rahman MS and Mohammadi H. Investigation of biological activities of the flowers of Lagerstroemia speciosa, the Jarul flower of Bangladesh. BMC Complement Altern Med 2018;18(1):231. doi: 10.1186/ s12906018-2286-6.

[72] Al-Snafi AE. A review on Lagerstroemia indica: A potential medicinal plant. IOSR Journal of Pharmacy 2019; 9(6): 36-42.

[73] Wadekar JB, Pawar PY, Nimbalkar VV, Honde BS, Jadhav PR and Nale SB. Anticonvulsant, anthelmintic and antibacterial activity of Lawsonia inermis. The Journal of Phytopharmacology 2016; 5(2): 53-55.

[74] Al-Snafi AE. A review on Lawsonia inermis: A potential medicinal plant. International Journal of Current Pharmaceutical Research 2019; 11(5):1-13.

[75] Ahmad K and Lewis JJ. On the pharmacology of petaline chloride, a convulsant alkaloid from Leontice leontopetalum Linn. J Pharm Pharmacol 1960;12:163-174.

[76] Al-Snafi AE. Constituents and pharmacological effects of Leontice leontopetalum- A review. To Chemistry Journal 2019; 3: 103-108. I

[77] Thirupathy KP, Tulshkar A and Vijaya C. Neuropharmacological activity of Lippia nodiflora Linn. Pharmacognosy Research 2011; 3(3):194-200.

[78] Al-Snai AE. Pharmacological and therapeutic effects of Lippia nodiflora (Phyla nodiflora). IOSR Journal of Pharmacy 2019; 9(8):15-25.

[79] Heidari MR, Dadollahi Z, Mehrabani M, Mehrabi H, Pourzadeh- Hosseini M, Behravan E and Etemad L. Study of antiseizure effects of Matricaria recutita extract in mice. Ann N Y AcadSci 2009; 1171: 300-304.

[80] Rostampour M, Aghaei I, Soltani B and Khakpour B. Effect of Matricaria chamomilla hydro-alcoholic extract on PTZ-induced seizure in male mice. Journal of Guilan University of Medical Sciences 2014; 23(89): 8-14.

[81] Hamad MN, Sulaiman AA, Numan IT and Abdul Rasak SA. Study of anticonvulsant effect of ethyl acetate fraction of Matricaria recutita extract in mice. International Journal of Pharmacy and Pharmaceutical Sciences 2014; 6(4): 224-227.

[82] Al-Snafi AE. Encyclopedia of chemical constituents and pharmacological effects of Iraqi medicinal plants. Rigi Publication, India, 2015.

[83] Singhal KG and Gupta GD. Some central nervous system activities of Nerium oleander linn (Kaner) flower extract. Trop J Pharm Res 2011; 10 (4): 455-461.

[84] Zia A Slddlqul BS , Begum S , Slddlqul S and Suria A. Studies on the constituents of the leaves of Nerium oleander on behavior pattern in mice. Journal of Ethnopharmacology 1995; 4: 33-39.

[85] Al-Snafi AE. Bioactive ingredients and pharmacological effects of Nerium oleander. IOSR Journal of Pharmacy 2020; 10(9): 19-32.

[86] Islam MH, Ahmad IZ and Salman MT. Neuroprotective effects of Nigella sativa extracts during germination on central nervous system. Pharmacogn Mag 2015; 11(Suppl 1): S182-189.

[87] -Hosseinzadeh H and Parvardeh S. Anticonvulsant effects of thymoquinone, the major constituent of Nigella sativa seeds, in mice. Phytomedicine 2004;11: 56-64.

[88] -Seghatoleslam M, Alipour F, Shafieian R, Hassanzadeh Z, Edalatmanesh MA, Sadeghnia HR and Hosseini M. The effects of Nigella sativa on neural damage after pentylenetetrazole induced seizures in rats. J Tradit Complement Med 2015; 6(3): 262-268. 
[89] Ilhan A, Gurel A, Armutcu F, Kamisli S and Iraz M. Antiepileptogenic and antioxidant effects of Nigella sativa oil against pentylenetetrazol induced kindling in mice. Neuropharmacology 2005; 49: 456-464.

[90] Ezz HS, Khadrawy YA and Noor NA. The neuroprotective effect of curcumin and Nigella sativa oil against oxidative stress in the pilocarpine model of epilepsy: a comparison with valproate. Neurochem Res 2011; 36: 2195-2204.

[91] Raza M, Alghasham AA, Alorainy MS and El-Hadiyah TM. Potentiation of valproate-induced anticonvulsant response by Nigella sativa seed constituents: The role of GABA receptors. Int J Health Sci 2008; 2: 15-25.

[92] Akhondian J, Parsa A and Rakhshande H. The effect of Nigella sativa L. (black cumin seed) on intractable pediatric seizures. Med SciMonit 2007; 13: CR555-559.

[93] Oliveira SJ, Porto AL, Estevam SC, Siqueira SR, Alves BP, Niculae SE, Blank FA, Almeida NR, Marchioro M and Junior QJL. Phytochemical screening and anticonvulsant property of Ocimum basilicum leaf essential oil. Boletin Latinoamericano y del Caibe de Plantas Medicinales y Aromaticas 2009; 8(3): 195-202.

[94] Al-Snafi AE. Chemical constituents and pharmacological effects of Ocimum basilicum- A review. International Journal of Pharmaceutical Research 2021; 13(2): 2997-3013.

[95] Hassanzadeh M, Sharifi N, Mahernia S, Rahimi N, Dehpour AR and Amanlou M. Effects of onopordia, a novel isolated compound from Onopordon acanthium, on pentylenetetrazole-induced seizures in mice: Possible involvement of nitric oxide pathway, Journal of Traditional and Complementary 2019; 30, https://doi.org/ 10.1016/j.jtcme.2019.11.005

[96] Pahuja M, Mehla J and Kumar Gupta Y. Anticonvulsant and antioxidative activity of hydroalcoholic extract of tuber of Orchis mascula in pentylenetetrazole and maximal electroshock induced seizures in rats. J Ethnopharmacol 2012;142(1):23-27.

[97] Al-Snafi AE. Pharmacological potential of Orchis mascula- A review. IOSR Journal of Pharmacy 2020;10(3):1-6.

[98] Senthil Kumar KK and Rajkapoor B. Effect of Oxalis corniculata L. extracts on antioxidant enzymes levels in rat brain after induction of seizures by MES and PTZ. International Journal of Biopharmaceutics 2010; 1(2): 58-61.

[99] Senthil Kumar KK and Rajkapoor B. Study on phytochemical profile and anti-epileptic activity of Oxalis corniculata L. International Journal of Biological \& Pharmaceutical Research 2010; 1: 34-39.

[100] Senthil Kumar KK and Rajkapoor B. Effect of Oxalis corniculata L. extracts on biogenic amines concentrations in rat brain after induction of seizure. International Journal of Phytopharmacology 2010; 1(2): 87-91. 